\title{
Decreased activity and accelerated apoptosis of neutrophils in the presence of natural polyphenols
}

\author{
Viera JANČINOVÁ 1, Tomáš PEREČKO 1, Juraj HARMATHA ${ }^{2}$, Radomír NOSÁL 1, Katarína DRÁBIKOVÁ 1 \\ 1 Institute of Experimental Pharmacology \& Toxicology, Slovak Academy of Sciences, SK-84104 Bratislava, Slovakia \\ 2 Institute of Organic Chemistry and Biochemistry, Academy of Sciences, v.v.i., CZ-16610 Prague, Czech Republic
}

ITX050212R02 • Received:02 May 2012 • Revised:25 May 2012 • Accepted:26 May 2012

\begin{abstract}
Prolonged or excessive formation and liberation of cytotoxic substances from neutrophils intensifies inflammation and the risk of tissue damage. From this perspective, administration of substances which are able to reduce activity of neutrophils and to enhance apoptosis of these cells may improve the therapy of pathological states connected with persistent inflammation. In this short review, neutrophil oxidative burst and apoptosis are presented as potential targets for pharmacological intervention. Effects of natural polyphenols (resveratrol, pterostilbene, pinosylvin, piceatannol, curcumin, $\mathrm{N}$-feruloylserotonin) are summarised, considering the ability of these compounds to affect inflammation and particularly neutrophil activity. The intended neutrophil inhibition is introduced as a part of a new strategy for pharmacological modulation of chronic inflammatory processes, focused on supporting innate antiinflammatory mechanisms and enhancing resolution of inflammation.
\end{abstract}

KEY WORDS: neutrophils; oxidative burst; apoptosis; natural polyphenols; resolution of inflammation

\section{New strategy for pharmacological modulation of inflammatory processes}

Resolution (i.e. termination of the defense/beneficial inflammation) has historically been viewed as a passive process, occurring as a result of withdrawal of proinflammatory signals. Thus most anti-inflammatory drugs in use suppress mechanisms engaged at the onset and progression of inflammation, but they are not targeted to support natural anti-inflammatory reactions. Only recently has the concept been established that resolution is an active process with a distinct set of chemical mediators (lipoxins, resolvins, protectins), involving decrease in activities of neutrophils and eosinophils, programmed death (apoptosis) of these cells, as well as their clearance from the site of inflammation by macrophages (Kohli \& Levy, 2009; Serhan et al., 2007, 2008). An abnormal, ineffective or absent regulation of these processes contributes

Correspondence address:

PharmDr. Viera Jančinová, PhD.

Institute of Experimental Pharmacology \& Toxicology,

Slovak Academy of Sciences

Dúbravská cesta 9, 84104 Bratislava, Slovak Republic

TEL.: +421-2-59410672 • E-MAIL: viera.jancinova@savba.sk to cellular dysfunction, tissue damage and to persisting inflammation. Moreover, defective regulation is thought to participate in the pathogenesis of chronic inflammatory diseases, such as asthma, rheumatoid arthritis or chronic obstructive pulmonary disease. Therefore the novel strategy of anti-inflammatory therapy is based upon pharmacological agents capable to enhance the resolution of inflammation (Sawatzky et al., 2006; Serhan et al., 2007; Hallett et al., 2008). Several drugs were found to promote pro-resolution pathways, such as aspirin (stimulates formation of lipoxins), glucocorticoids (activate macrophages and accelerate apoptosis of eosinophils), methotrexate (increases synthesis of endogenous anti-inflammatory mediators), as well as substances modulating neutrophil activity and apoptosis (Yasui \& Baba, 2006; Rossi et al., 2007; Filep \& El Kebir, 2009).

\section{Pro-inflammatory activity of neutrophils}

Neutrophils (neutrophilic polymorphonuclear leukocytes) represent the body's primary line of defense against invading pathogens. Nevertheless, recently they 
have been increasingly studied as active participants in the initiation and progression of many pathological states, such as rheumatoid polyarthritis, carcinoma, allergy or ischaemia-reperfusion. All these conditions are generally accompanied by dysregulated, persistent and excessive activation of neutrophils, resulting in damage of adjacent tissues by neutrophil "destructive hardware" - by reactive oxygen species, cytotoxic proteins and proteolytic enzymes (Cascao et al., 2009, 2010; Fialkow et al., 2007; Wright et al., 2010). In rheumatoid arthritis, neutrophil derived oxidants can induce cartilage degradation, depolymerise hyaluronan and decrease its lubricative properties. Further they can reduce the protective antioxidant and antiproteinase capacity of synovial fluid and thus participate in joint erosion (Cascao et al., 2009; Edwards \& Hallett, 1997). Besides, neutrophils are capable to release inflammatory mediators (eicosanoids,

Box 1. Factors regulating neutrophil apoptosis.

Pro-apoptotic factors

- Bcl-2 (B-cell lymphoma-2) proteins Bak, Bax, Bid control integrity of mitochondrial membrane

- Bcl-2 proteins Bad, Bim activate Bak/Bax and inhibit antiapoptotic $\mathrm{BCl}-2$ proteins

- Cytochrome c, APAF1 (apoptotic protease-activating factor-1) activate caspase-9

- Caspases (cystein-dependent aspartate-directed proteases); initiate caspases- 8 and -9 activate the executioner caspase-3, responsible for cytomorphological alterations

- TNFa (tumour necrosis factor-a, high concentrations) activates caspase-8

- Reactive oxygen intermediates cause DNA damage, upregulate death receptor clustering and activation of caspase-8

- Cathepsin D activates caspase-8 and Bid

- Calpain 1 regulates Bax and caspase-3 activation

- Inhibitors of CDK (cycline-dependent kinase), e.g. R-roscovitine, reduce $\mathrm{Mcl}-1$ level

\section{Anti-apoptotic factors}

- Bcl-2 (B-cell lymphoma-2) proteins $\mathbf{M c l}-\mathbf{1}, \mathbf{B c l}-\mathbf{X}_{\mathbf{L}}, \mathbf{A} \mathbf{1}$ control integrity of mitochondrial membrane

- XIAP (X-linked inhibitor of apoptosis protein) inhibits activity of caspases -3 and -9

- $\quad$ AMP/protein kinase $A$ inhibits caspase-8

- $\mathbf{N F - \kappa B ~ ( n u c l e a r ~ f a c t o r - K B ) ~ i n c r e a s e s ~ t r a n s c r i p t i o n ~ o f ~}$ survival proteins $\mathrm{Mcl}-1$ and $\mathrm{A} 1$

- $\quad$ 38MAPK (mitogen-activated protein kinase) inhibits caspases -8 and -3

- PI3K (phosphoinositide-3-kinase) inhibits Bad and Bax activation

- $\quad$ TNFa (tumour necrosis factor-a, lower concentrations) stimulates expression of A1

- $\quad$ GM-CSF (granulocyte macrophage-colony stimulating factor) upregulates antiapoptotic pathways such as PI3K, blocks Bid/Bax redistribution

- $\quad$ LPS (lipopolysaccharide) upregulates pro-survival factors Mcl-1 and A1 chemokines, cytokines), which along with their altered recruitment and delayed apoptosis, have the potential to maintain permanent inflammation (Cascao et al., 2010; Wright et al., 2010). The treatment of diseases associated with chronic inflammation should thus be focused also on neutrophil functions; formation of reactive oxygen intermediates and apoptosis of these cells represent two promising targets for pharmacological intervention.

\section{Formation of reactive oxygen species}

Reactive oxygen species (ROS) are produced in large quantities when neutrophils are stimulated by proinflammatory agents or by particles such as bacteria. This process, known as "oxidative burst", is initiated by the activation of NADPH oxidase (NADPH: nicotine amide adenine dinucleotide phosphate). During this process, the cytosolic phox proteins (phox: phagocyte oxidase) p47phox, p67phox, p40phox and Rac2 translocate to the plasma membrane or to membranes of specific granules, where they associate with the membrane-bound components (p22phox gp91phox) to assemble the catalytically active oxidase (El-Benna et al., 2010; Ambruso et al., 2004). A partial association of NADPH oxidase components was observed in neutrophils primed with TNF $\alpha$, GM-CSF or LPS. This configuration, not sufficient for ROS generation, amplifies the oxidative burst initiated by subsequent stimulation of neutrophils (Sheppard et al., 2005).

Activated NADPH oxidase transfers an electron from NADPH to molecular oxygen, generating superoxide anion. This precursor of other ROS is immediately transformed into hydrogen peroxide $\left(\mathrm{H}_{2} \mathrm{O}_{2}\right)$, spontaneously or through enzymatic dismutation by superoxide dismutase. Interaction between $\mathrm{H}_{2} \mathrm{O}_{2}$ and superoxide anion can give rise to the hydroxyl radical, one of the most powerful oxidants. Moreover, hydrogen peroxide is a substrate of myeloperoxidase, which catalyses its transformation into highly toxic molecules such as hypochlorous acid, chloramines and tyrosyl radicals (El-Benna et al., 2010; Robinson, 2009). The percentage of particular oxygen metabolites was found to be dependent on the mechanism of neutrophil activation (Takahashi et al., 1991).

Activated neutrophils form and liberate reactive oxygen species both extra- and intracellularly (El-Benna et al., 2010; Karlsson \& Dahlgren, 2002). Oxidative burst arising inside neutrophils is much less pronounced and reaches maximum values later than the external ROS formation. The intracellular oxidants fulfill a regulatory role and participate in the initiation of neutrophil apoptosis (Luo \& Loison, 2008; Witko-Sarsat et al., 2011). The substantial part of reactive oxygen species is formed at neutrophil plasma membranes and is liberated extracellularly or into phagosomes. These radicals are involved in the elimination of pathogens, however their overproduction may result in damage of surrounding tissues. Confirmation of the destructive role of radicals in pathological states associated with persistent inflammation (Halliwell \& Whiteman, 2004; Lonkar \& Dedon, 2011) initiated an 
intensive search for substances with antioxidant activity. Since the optimum therapy is expected to minimise tissue damage without reduction of the physiological function of neutrophils, separate analysis of extra- and intracellular effects of antioxidants is of particular importance. The chemiluminescence method, based on different abilities of luminol and isoluminol to cross biological membranes and to interact with radicals inside cells, represents an effective tool for such differentiation (Drábiková et al., 2006; 2009).

\section{Neutrophil apoptosis}

Apoptosis is a complex physiological mechanism in which a cell undergoes programmed death as a result of withdrawal of survival factors and/or of exposure to pro-apoptotic signals. It represents a sensitive and highly regulated process (Box 1), which includes mitochondrial membrane permeabilisation, followed by the release of cytochrome $\mathrm{c}$ and other pro-apoptotic proteins into the cytosol, gradual activation of caspases, DNA fragmentation, chromatin condensation, loss of membrane asymmetry and formation of apoptotic bodies. In contrast to necrosis, apoptosis saves the integrity of neutrophil membranes and prevents the discharge of cytotoxic and proteolytic contents into the surrounding tissues (Luo \& Loison, 2008; Witko-Sarsat et al., 2011; Hallett et al., 2008). Alterations in plasma membrane (e.g. externalisation of phosphatidylserine) facilitate the recognition and clearance of apoptotic neutrophils by macrophages, resulting in safe removal of these cells from the site of inflammation. Moreover, on recognising apoptotic neutrophils, macrophages are programmed to upregulate the production of anti-inflammatory mediators such as transforming growth factor (TGF)- $\beta$ and interleukin (IL)-10, resulting in reduction of the inflammatory process (Duffin et al., 2010; Nussbaum \& Shapira, 2011). Due to these facts, better comprehension of neutrophil apoptosis might lead to novel therapeutic strategies designed to enhance resolution of inflammation without tissue damage (Witko-Sarsat et al., 2011). At present, a great deal of substances directing neutrophils to apoptosis are tested in vitro as well as under conditions of experimental inflammation (Hallett et al., 2008; $\mathrm{Hu}$ et al., 2005; Sawatzky et al., 2006; Derouet et al., 2006; Serhan et al., 2007; Jagetia \& Aggarwal, 2007). The most intensively examined substances have been inhibitors of nuclear factor- $\mathrm{kB}$, compounds modifying the expression of pro- and anti-apoptotic Bcl-2 (B-cell lymphoma-2) proteins or PI3K (phosphoinositide-3-kinase) and CDK (cycline-dependent kinase) inhibitors.

\section{Neutrophils as potential targets for pharmacological intervention}

Prolonged or excessive formation and liberation of cytotoxic substances from neutrophils, accompanied by delayed apoptosis of these cells, intensify inflammation and the risk of tissue damage (Figure 1). From this

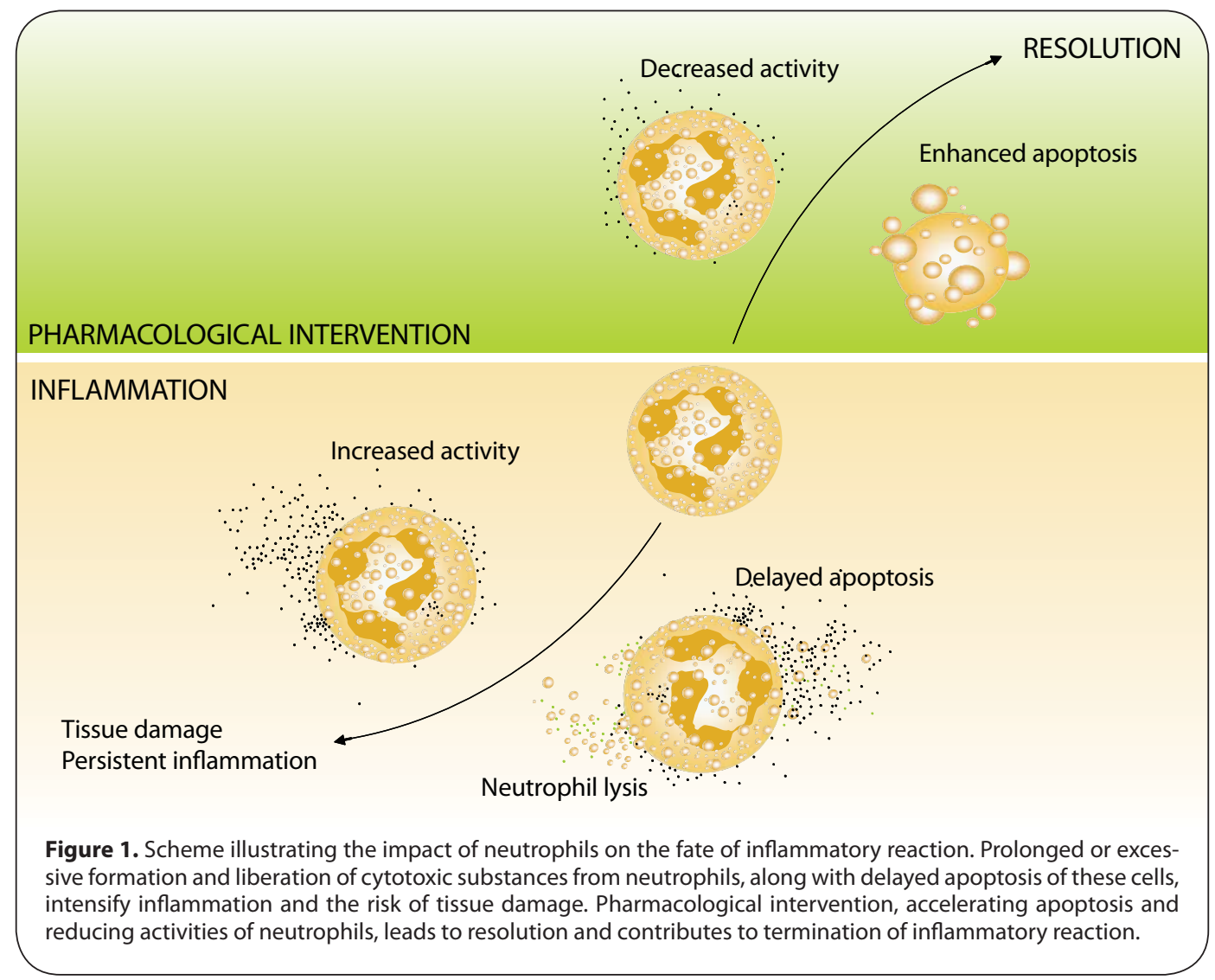


Table 1. Mechanisms of the anti-inflammatory activity of natural polyphenols.

\begin{tabular}{|c|c|c|}
\hline \multicolumn{2}{|l|}{ Compound } & References \\
\hline Resveratrol & 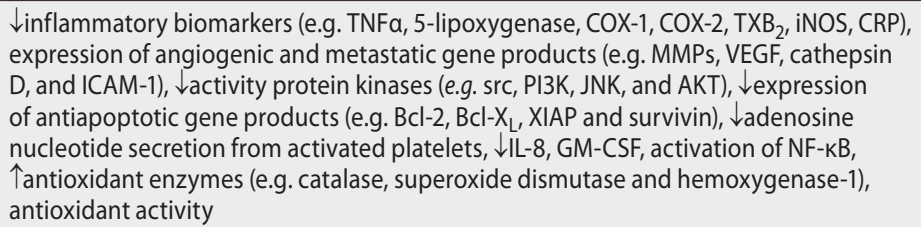 & $\begin{array}{l}\text { Alarcón de la Lastra \& Villegas, 2005; } \\
\text { Haricumar \& Aggarwal, 2008; } \\
\text { Anonym, } 2010\end{array}$ \\
\hline Pterostilbene & $\begin{array}{l}\downarrow \text { activation of NF-KB, } \downarrow \text { COX-1, } \downarrow \text { COX-2, } \downarrow \text { iNOS } \\
\downarrow \text { production of pro-inflammatory mediators (PGE } 2, \text { TNFa), antioxidant activity }\end{array}$ & $\begin{array}{l}\text { Perečko et al., 2010; } \\
\text { Cichocki et al., 2008; } \\
\text { Remsberg et al., 2008; } \\
\text { Paul et al., 2009; } \\
\text { Anonym, 2010; }\end{array}$ \\
\hline Pinosylvin & $\begin{array}{l}\text { antioxidant activity, } \downarrow \text { activation of NF-KB, } \\
\downarrow \text { production of pro-inflammatory mediators, } \\
\downarrow \text { COX-2 and iNOS expression }\end{array}$ & $\begin{array}{l}\text { Roupe et al., 2006; } \\
\text { Lee et al., 2006; } \\
\text { Park et al., 2005; } \\
\text { Park et al., } 2011\end{array}$ \\
\hline Piceatannol & $\begin{array}{l}\downarrow \text { Syk, } \downarrow \text { COX-2, } \downarrow \text { iNOS, antioxidant activity, } \\
\downarrow \text { MPO, } \downarrow \text { PGE } 2, \downarrow \text { pro-inflammatory cytokines }\end{array}$ & $\begin{array}{l}\text { Roupe et al., 2006; } \\
\text { Son et al., 2010; } \\
\text { Kim et al., } 2008\end{array}$ \\
\hline Curcumin & $\begin{array}{l}\downarrow \text { activation of NF-KB, } \downarrow \text { overexpression of inflammatory cytokines and adhesion } \\
\text { molecules, } \downarrow \text { activity of COX-2, iNOS and LOX, antioxidant activity }\end{array}$ & $\begin{array}{l}\text { Jurenka, 2009; } \\
\text { Srivastava et al., 2011; } \\
\text { Aggarwal \& Sung, } 2009\end{array}$ \\
\hline $\mathrm{N}$-feruloyl serotonin & $\begin{array}{l}\text { antioxidant activity, } \downarrow \text { LDL oxidation, } \downarrow \text { activation of caspase- } 3, \downarrow \text { ROS-dependent } \\
\text { adhesion, } \downarrow \text { migration of monocytes to endothelial cells, } \downarrow \text { activation of NF-KB }\end{array}$ & $\begin{array}{l}\text { Piga et al., 2009; } \\
\text { Piga et al., } 2010\end{array}$ \\
\hline
\end{tabular}

Abbreviations used: AKT: protein kinase B; BCl-2: B-cell lymphoma 2; BCl- $\mathbf{X}_{\mathbf{L}}$ : B-cell lymphoma-extra large; COX: cyclooxygenase; CRP: C-reactive protein; GM-CSF: granulocyte-macrophage colony-stimulating factor; ICAM: intracellular adhesion molecule; IL-8: interleukin 8; iNOS: inducible nitric oxide synthase; JNK: C-Jun N-terminal kinase; LDL: low density lipoprotein; LOX: lipoxygenase; MAC-1: macrophage-1 antigen; MAPK: mitogen-activated

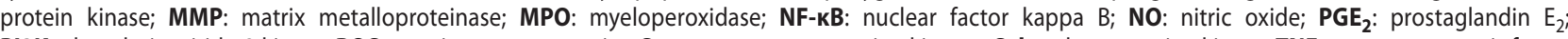
PI3K: phosphoinositide-3 kinase; ROS: reactive oxygen species; Src: non-receptor tyrosine kinases; Syk: spleen tyrosine kinase; TNFa: tumour necrosis factor alpha; $\mathbf{T X B}_{2}$ : thromboxane $\mathrm{B}_{2}$; VCAM-1: vascular cell adhesion protein; VEGF: vascular endothelial growth factor; XIAP: X-linked inhibitor of apoptosis protein

\begin{tabular}{|c|c|c|}
\hline Compound & & References \\
\hline Resveratrol & $\begin{array}{l}\downarrow \text { superoxide anion, } \downarrow \text { hypochlorous acid, } \downarrow \text { chemotaxis } \\
\downarrow 5 \text {-LOX, } \downarrow \text { myeloperoxidase, } \downarrow \text { ROS formation } \\
\downarrow \text { expression ICAM-1, VCAM- } 1, \text { MAC-1, } \beta 2 \text {-integrin } \\
\downarrow \text { activity protein kinases (MAPK, JNK) } \\
\downarrow \text { elastase, } \downarrow \beta \text {-glucuronidase, } \downarrow \text { chemotaxis, } \\
\downarrow \text { NO production }\end{array}$ & $\begin{array}{l}\text { Perečko et al., 2008; } \\
\text { Alarcón de la Lastra \& Villegas, 2005; } \\
\text { Cavallaro et al., 2003; } \\
\text { Adams et al., 2005; } \\
\text { Kohnen et al., } 2007\end{array}$ \\
\hline Pterostilbene & $\downarrow$ ROS formation & $\begin{array}{l}\text { Perečko et al., 2008; } \\
\text { Perečko et al., } 2010\end{array}$ \\
\hline Pinosylvin & $\downarrow 5$-LOX, $\downarrow$ ROS formation & $\begin{array}{l}\text { Perečko et al., 2008; } \\
\text { Adams et al., } 2005\end{array}$ \\
\hline Piceatannol & $\begin{array}{l}\downarrow \text { Syk, } \downarrow \text { phagocytosis and adhesion, } \uparrow \text { apoptosis, } \downarrow T N F a, \downarrow P G E_{2}, \downarrow I L-8, \downarrow R O S \text { production, } \\
\downarrow \text { p40phox phosphorylation }\end{array}$ & $\begin{array}{l}\text { Ennaciri \& Girard, 2009; } \\
\text { Richard et al., 2005; } \\
\text { Jančinová et al., 2011a }\end{array}$ \\
\hline Curcumin & $\begin{array}{l}\downarrow \text { aggregation, } \downarrow \text { ROS production, } \uparrow \text { apoptosis, } \\
\downarrow \text { chemotaxis, } \downarrow \text { protein kinase C activation, } \\
\downarrow \text { 5-LOX }\end{array}$ & $\begin{array}{l}\text { Srivastava et al., 2011; } \\
\text { Jančinová et al., 2009; } \\
\text { Jančinová et al., 2011; } \\
\text { Prasad et al., } 2004\end{array}$ \\
\hline $\mathrm{N}$-feruloyl serotonin & $\downarrow R O S$ production, $\downarrow$ protein kinase $C$ activation & $\begin{array}{l}\text { Nosál' et al., 2011; } \\
\text { Nosál' et al., } 2010\end{array}$ \\
\hline
\end{tabular}

Abbreviations used: see Table 1 .

perspective, the pharmacological intervention capable to enhance the resolution of inflammation through modulation of its important inputs - activity and apoptosis of neutrophils - represents a prospective alternative. To date, the intended neutrophil inhibition has not been involved in the therapy of pathological states connected with persistent inflammation. Since this therapy is long-lasting and often accompanied with many adverse reactions, co-application of substances which are able to reduce the activity of neutrophils and/or to enhance apoptosis of these cells may lead to its increased effectiveness and reduced toxicity. In this regard, the group of natural polyphenols could provide appropriate candidates for such a combined therapy. 


\section{Natural polyphenols and their effects on neutrophils}

Phenolic compounds of plant origin integrate a large group of plant secondary metabolites with remarkably rich structural variations. They are generally characterised as aromatic compounds, possessing one or more hydroxyls attached directly to the aromatic (phenolic) moiety of the molecule. The most common types of plant phenols involve phenolic acids, coumarins, stilbenes, flavonoids, lignans, condensed tannins and lignins (Harmatha et al., 2011). In this review, effects of two derivatives of ferulic acid (curcumin, $\mathrm{N}$-feruloylserotonin) and four stilbenes (resveratrol, pterostilbene, pinosylvin, piceatannol) are summarised, considering the ability of these compounds to affect inflammation and particularly neutrophil activity.

Besides their broad structural variability, natural polyphenols are characterised by a great variety of biological effects. Beneficial anti-inflammatory activities, most completely examined for resveratrol and curcumin (Table 1), have been attributed to the capacity of plant phenols to prevent activation of nuclear factor-kappa B and the subsequent overexpression of pro-inflammatory mediators - cytokines, adhesion molecules, cyclooxygenase-2, 5-lipoxygenase, myeloperoxidase or inducible nitric oxide synthase. Minor attention has been concentrated on the effect of polyphenols on the activity of neutrophils (Table 2). The existing results suggest that plant polyphenols can control neutrophil activity by multiple mechanisms and therefore may be more efficient than synthetic inhibitors directed against one particular enzyme or receptor (Burgos et al., 2009).

\section{Acknowledgement}

The work was supported by The Agency of the Ministry of Education, Science, Research and Sport of the Slovak Republic for the Structural Funds of EU, OP R\&D of ERDF by realization of the Project „Transfer of Knowledge and Technologies from Research and Development in Toxicology on Evaluation of Environmental and Health risk"(ITMS Code 26240220005) and by grant VEGA 2/0003/10.

\section{REFERENCES}

Adams M, Pacher T, Greger H, Bauer R. (2005). Inhibition of leukotriene biosynthesis by stilbenoids from Stemona species. J Nat Prod 68: 83-85.

Aggarwal BB, Sung B. (2009). Pharmacological basis for the role of curcumin in chronic diseases: an age-old spice with modern targets. Trends Pharmacol Sci 30: 85-94.

Alarcón de la Lastra C, Villegas I. (2005). Resveratrol as an anti-inflammatory and anti-aging agent: Mechanisms and clinical implications. Mol Nutr Food Res 49: 405-430.

Ambruso DR, Cusack N, Thurman G. (2004). NADPH oxidase activity of neutrophil specific granules: requirements for cytosolic components and evidence of assembly during cell activation. Mol Gen Metab 81: 313-321.

Anonym. (2010). Resveratrol Monograph. Alter Med Rev 15: 152-158.
Anonym. (2010). Pterostilbene Monograph. Alter Med Rev 15: 159-163.

Burgos RA, Hidalgo MA, Fiqueroa CD, Conejeros I, Hancke JL. (2009). New potential targets to modulate neutrophil function in inflammation. MiniRev Med Chem 9: 153-168.

Cascao R, Rosário HS, Fonseca JE. (2009). Neutrophils: warriors and commanders in immune mediated inflammatory diseases. Acta Reumatol Port 34: 313-326.

Cascao R, Rosário HS, Souto-Carneiro MM, Fonseca JE. (2010). Neutrophils in rheumatoid arthritis: More than simple final effectors. Autoimmun Rev 9: 531-535.

Cavallaro A, Ainis T, Bottari C, Fimiani V. (2003). Effect of resveratrol on some activities of isolated and in whole blood human neutrophils. Physiol Res 52: $555-562$.

Cichocki M, Paluszczak J, Szaefer H, Piechowiak A, Rimando AM, BaerDubowska W. (2008). Pterostilbene is equally potent as resveratrol in inhibiting 12-O-tetradecanoyl phorbol-13-acetate activated NFKB, AP-1, COX-2, and iNOS in mouse epidermis. Mol Nutr Food Res 52: 62-70.

Derouet M, Thomas L, Moulding DA, Akgul C, Cross A, Moots RJ, Edwards SW. (2006). Sodium salicylate promotes neutrophil apoptosis by stimulating caspase-dependent turnover of Mcl-1. J Immunol 176: 957-965.

Drábiková K, Jančinová V, Nosál' R, Solík P, Murín J, Holomáňová D. (2006). On the antioxidant activity of carvedilol in human polymorphonuclear leukocytes in vitro and ex vivo. Neuroendocrinol Lett 27: 138-140.

Drábiková K, Perečko T, Nosál' R, Bauerová K, Poništ S, Mihalová D, Kogan G, Jančinová V. (2009). Glucomannan reduces neutrophil free radical production in vitro and in rats with adjuvant arthritis. Pharmacol Res 59: 399-403.

Duffin R, Leitch AE, Fox S, Haslett C, Rossi AG. (2010). Targeting granulocyte apoptosis: mechanisms, models, and therapies. Immunol Rev 236: 28-40.

Edwards SW, Hallett MB. (1997). Seeing the wood for the trees: the forgotten role of neutrophils in rheumatoid arthritis. Immunol Today 18: 320-324.

El-Benna J, Dang PMC, Périanin A. (2010). Peptide-based inhibitors of the phagocyte NADPH oxidase. Biochem Pharmacol 80: 778-785.

Ennaciri J, Girard D. (2009). IL-4R (alpha), a new member that associates with Syk kinase: implication in IL-4-induced human neutrophil functions. J Immunol 183: 5261-5269.

Fialkow L, Wang Y, Downey GP. (2007). Reactive oxygen and nitrogen species as signaling molecules regulating neutrophil function. Free Rad Biol Med 42: 153-164.

Filep JG, El Kebir D. (2009). Neutrophil apoptosis: a target for enhancing the resolution of inflammation. J Cell Biochem 108: 1039-1046.

Hallett JM, Leitch AE, Riley NA, Duffin R, Haslett C, Rossi AG. (2008). Novel pharmacological strategies for driving inflammatory cell apoptosis and enhancing the resolution of inflammation. Trends Pharmacol Sci 29: 250-257.

Halliwell B, Whiteman M. (2004). Measuring reactive species and oxidative damage in vivo and in cell culture: how should you do it and what do the results mean? Brit J Pharmacol 142: 231-255.

Haricumar KB, Aggarwal BB. (2008). Resveratrol: a multitargeted agent for age-associated chronic diseses. Cell cycle 7: 1020-1035.

Harmatha J, Zídek Z, Kmoníčková E, Šmidrkal J. (2011). Immunobiological properties of selected natural and chemically modified phenylpropanoids. Interdisc Toxicol 4: 5-10.

Hu M, Du Q, Vancurova I, Lin X, Miller EJ, Simms HH, Wang P. (2005). Proapoptic effect of curcumin on human neutrophils: Activation of the p38 mitogen-activated protein kinase pathway. Crit Care Med 33: 2571-2578.

Jagetia GC, Aggarwal BB. (2007). „Spicing up“of the immune system by curcumin. J Clin Immunol 27: 19-35.

Jančinová V, Perečko T, Nosál'R, Koštálová D, Bauerová K, Drábiková K. (2009). Decreased activity of neutrophils in the presence of diferuloylmethane (curcumin) involves protein kinase C inhibition. Eur J Pharmacol 612: 161-166.

Jančinová V, Perečko T, Nosál' R, Mihalová D, Bauerová K, Drábiková K. (2011). Pharmacological regulation of neutrophil activity and apoptosis. Contribution to new strategy for modulation of inflammatory processes. Interdisc Toxicol 4: 101-104

Jančinová V, Perečko T, Drábiková K, Nosál' R, Sviteková K. (2011a). Piceatannol, a natural analogue of resveratrol, inhibits oxidative burst of human neutrophils. Interdisc Toxicol 4: A35-A36.

Jurenka JS. (2009). Anti-inflammatory properties of curcumin, a major constituent of Curcuma longa: A review of preclinical and clinical research. Altern Med Rev 14: 141-153. 
Karlsson A, Dahlgren C. (2002). Assembly and activation of the neutrophil NADPH oxidase in granule membranes. Antioxid Redox Signal 4: 49-60.

Kim YH, Kwon HS, Kim DH, Cho HJ, Lee HS, Jun JG, Park JH, Kim JK. (2008). Piceatannol, a stilbene present in grapes, attenuates dextran sulfate sodium-induced colitis. Int Immunopharmacol 8: 1695-1702.

Kohli P, Levy BD. (2009). Resolvins and protectins: mediating solutions to inflammation. Br J Pharmacol 158: 960-971.

Kohnen S, Franck T, Van Antwerpen P, Boudjeltia KZ, Mouithys-Mickalad A, Deby C, Moguilevsky N, Deby-Dupont G, Lamy M, Serteyn D. (2007). Resveratrol inhibits the activity of equine neutrophil myeloperoxidase by a direct interaction with the enzyme. J Agric Food Chem 55: 8080-8087.

Lee J, Jung E, Lim J, Lee J, Hur S, Kim SS, Lim S, Hyun CG, Kim YS, Park D. (2006). Involvement of nuclear factor-kappa B in the inhibition of pro-inflammatory mediators by pinosylvin. Planta Med 72: 801-806.

Lonkar P, Dedon PC. (2011). Reactive species and DNA damage in chronic inflammation: reconciling chemical mechanisms and biological fates. Int $J$ Cancer 128: 1999-2009.

Luo HR, Loison F. (2008). Constitutive neutrophil apoptosis: mechanisms and regulation. Am J Hemato/ 83: 288-295.

Nosál' R, Perečko T, Jančinová V, Drábiková K, Harmatha J, Sviteková K. (2010). Suppression of oxidative burst in human neutrophils with the naturally occurring serotonin derivative isomer from Leuzea carthamoides. Neuroendocrinol Lett 31: 69-72.

Nosál' R, Perečko T, Jančinová V, Drábiková K, Harmatha J, Sviteková K. (2011). Naturally appearing $\mathrm{N}$-feruloylserotonin isomers suppress oxidative burst of human neutrophils at the protein kinase C level. Pharmacol Rep 63: 790798

Nussbaum G, Shapira L. (2011). How has neutrophil research improved our understanding of periodontal pathogenesis. J Clin Periodontol 38: 49-59.

Park EJ, Ahn YH, Pyee JH, Park HJ, Chung HJ, Min HY, Hong JY, Kang YJ, Bae IK, Lee SK. (2005). Suppressive effects of pinosylvin, a natural stilbenoid, on cyclooxygenase-2 and inducible nitric oxide synthase and the growth inhibitor of cancer cells. Proc Amer Assoc Cancer Res 46: 176.

Park EJ, Min HY, Chung HJ, Ahn YH, Pyee JH, Lee SK. (2011). Pinosylvin suppresses LPS-stimulated inducible nitric oxide synthase expression via the MyD88-independent, but TRIF-dependent downregulation of IRF-3 signaling pathway in mouse macrophage cells. Cell Physiol Biochem 27: 353-362.

Paul S, Rimando AM, Lee HJ, Ji Y, Reddy BS, Suh N. (2009). Anti-inflammatory action of pterostilbene is mediated through the 38 mitogen-activated protein kinase pathway in colon cancer cells. Cancer Prev Res (Phila) 2: 650-657.

Perečko T, Jančinová V, Drábiková K, Nosál' R, Harmatha J. (2008). Structureefficiency relationship in derivatives of stilbene. Comparison of resveratrol, pinosylvin and pterostilbene. Neuroendocrinol Lett 29: 802-805.

Perečko T, Drábiková K, Račková L, Číž M, Podborská M, Lojek A, Harmatha J, Šmidrkal J, Nosál' R, Jančinová V. (2010). Molecular targets of the natural antioxidant pterostilbene: effect on protein kinase C, caspase- 3 and apoposis in human neutrophils in vitro. Neuroendocrinol Lett 31: 84-90.

Piga R, Naito Y, Kokura S, Handa O, Yoshikawa T. (2009). Inhibitory effect of serotonin derivatives on high glucose-induced adhesion and migration of monocytes on human aortic endothelial cells. Br J Nutr 102: 264-272.
Piga R, Naito Y, Kokura S, Handa O, Yoshikawa T. (2010). Protective effect of serotonin derivatives on glucose-induced damage in $\mathrm{PC12}$ rat pheochromocytoma cells. Br J Nutr 103: 25-31.

Prasad NS, Raghavendra R, Lokesh BR, Naidu KA. (2004). Spice phenolics inhibit human PMNL 5-lipoxygenase. Prostaglandins Leukot Essent Fatty Acids 70: 521-528.

Remsberg CM, Yańez JA, Ohgami Y, Vega-Villa KR, Rimando AM, Davies NM. (2008). Pharmacometrics of Pterostilbene: Preclinical pharmacokinetics and metabolism, anticancer, antiinflammatory, antioxidant and analgesic activity. Phytother Res 22: 169-179.

Richard N, Porath D, Radspieler A, Schwager J. (2005). Effects of resveratrol, piceatannol, tri-acetoxystilbene, and genistein on the inflammatory response of human peripheral blood leukocytes. Mol Nutr Food Res 49: 431442.

Robinson JM. (2009). Phagocytic leukocytes and reactive oxygen species. Histochem Cell Biol 131: 465-469.

Rossi AG, Hallett JM, Sawatzki DA, Teixeira MM, Haslett C. (2007). Modulation of granulocyte apoptosis can influence the resolution of inflammation. Biochem Soc Trans 35: 288-291

Roupe KA, Remsberg CM, Yanez JA, Davies NM. (2006). Pharmacometrics of stilbenes: Seguing towards the clinic. Curr Clin Pharmacol 1: 81-101.

Sawatzky DA, Willoughby DA, Colville-Nash PR, Rossi AG. (2006). The involvement of the apoptosis-modulating proteins ERK 1/2, BCl- $x_{\mathrm{L}}$ and $\mathrm{Bax}$ in the resolution of acute inflammation in vivo. Am J Pathol 168: 33-41.

Serhan CN, Brain SD, Buckley CD, Gilroy DW, Haslett C, O'Neill LAJ, Perretti M, Rossi AG, Wallace JL. (2007). Resolution of inflammation: state of the art, definitions and terms. FASEB J 21: 325-332.

Serhan CN, Yacoubian S, Yang R. (2008). Anti-inflammatory and pro-resolving lipid mediators. Annu Rev Pathol 3: 279-312.

Sheppard FR, Kelher MR, Moore EE, McLaughlin NJD, Banerjee A, Silliman CC. (2005). Structural organization of the neutrophil NADPH oxidase: phosphorylation and translocation during priming and activation. $J$ Leukoc Biol 78: $1025-1042$.

Son PS, Park SA, Na HK, Jue DM, Kim S, Surh YJ. (2010). Piceatannol, a catechol-type polyphenol, inhibits phorbol ester-induced NFkappa B activation and cyclooxygenase-2 expression in human breast epithelial cells: cysteine 179 of IKKbeta as a potential target. Carcinognesis 31: 1442-1449.

Srivastava RM, Singh S, Dubey SK, Misra K, Khar A. (2011). Immunomodulatory and therapeutic activity of curcumin. Int Immunopharmacol 11: 331 341.

Takahashi R, Edashige K, Sato EF, Inoue M. (1991). Luminol chemiluminescence and active oxygen generation by activated neutrophils. Arch Biochem Biophys 285: 325-330.

Witko-Sarsat V, Pederzoli-Ribeil M, Hirsh E, Sozzani S, Cassatella MA. (2011). Regulating neutrophil apoptosis: new players enter the game. Trends Immunol 32: 117-124.

Wright HL, Moots RJ, Bucknall RC, Edwards SW. (2010). Neutrophil function in inflammation and inflammatory diseases. Rheumatology 49: 1618-1631.

Yasui K, Baba A. (2006). Therapeutic potential of superoxide dismutase (SOD) for resolution of inflammation. Inflamm Res 55: 359-363. 